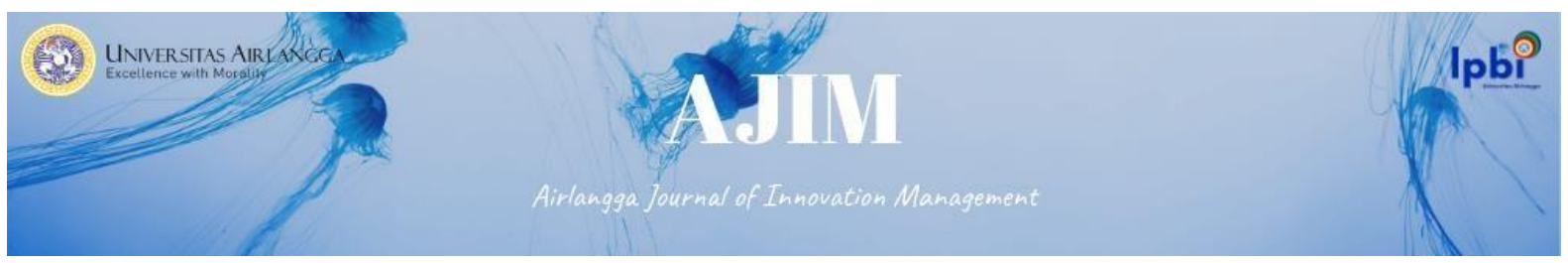

Vol. 2 No.1 Juni 2021

e-ISSN: 2722-5062

DOI : 10.20473/ajim.vvii.25384

\title{
IMPROVING PERFORMANCE THROUGH REST TIME SYSTEM DESIGN: PHYSOLOGICAL INTEGRATION AND QUALITY FUNCTION DEVELOPMENT
}

\author{
Johan Alfian Pradana \\ Industrial Engineering, Faculty of Engineering, Universitas Kadiri \\ Corresponding email: zoehuntz34@gmail.com
}

\begin{abstract}
Overwork is the cause of above-normal pulses. Rest time role needed to re-normalize pulse. The research aims to design the right rest system with a Physiology and Quality Function Deployment approach in tofu craftsmen of the male gender in Kediri district. The method with the first stage performs measurements of pulse, oxygen consumption, metabolism, energy and intervention. The second stage performs a set of attributes needs of craftsmen and technical responses from MSME owners know with the final results of attribute selection based on the highest weight. The results showed an effective rest time of 233.9 minutes per 6 hours of work reviewed from the physiological approach. Rest time with Quality Function Deployment approach weighing 192.02 is worship with a time of 20 minutes; sleep weight 182.25 with a time of 60 minutes; evaluation weighed 157.84 with a time of 120 minutes; heating weighs 152.96 with a time of 20 minutes; and drinking water weighed 121.85 with a time of 13.9 minutes. With this result, a break design system can be applied to improve the performance of tofu craftsmen. Subsequent development may lead to reduced rest time but result in greater performance.
\end{abstract}

Keywords: Workload, Physiology, Quality function deployment, Tofu Craftman

\section{Introduction.}

Blabak Kediri Regency is an area in East Java. The area has a small industry, namely tofu craftsmen. Almost every house has a small industry which operates predominantly from 13.00 WIB to 17.00 WIB. The process of cooking tofu from washing the soybeans to the ready-to-market cutting process. Stages of cooking tofu with static workload criteria, namely filtering out. Process of filtering out tofu is tearing the gauze filter on the tofu cooking tub. The cooking tub has a temperature of nearly $1500 \mathrm{C}$ in one dish. The hot temperature comes from burning wood and appearance of steam in tofu cooking tub due to boiling process. The longest one-time cooking process is 2 hours with longest filtering process is 30 minutes.

The filtering temperature of tofu which reaches $1500 \mathrm{C}$ makes tofu craftsmen feel the impact. One of impacts of this activity is work fatigue. This fatigue can have an effect on your performance every time you work (Caldwell et al., 2019). The appearance of work fatigue also signals a need for proper rest periods. When taking a post-work break, craftsman knows he is not making good use of this time. Every time he works he feel tired constantly. The craftsman knows that in filtering process he feels static complaints. Where every job feels sleepy, tired and less enthusiastic. Therefore, $=$ break time 


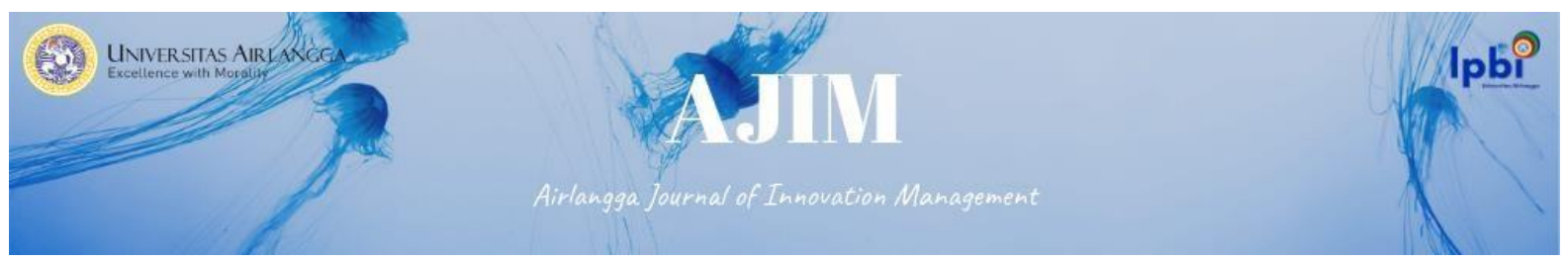

requires an activity design based on what craftsmen need and response of UMKM owner to know to answer these needs.

Improper resting time with high workload causes pulse to exceed normal limits. In normal work, pulse for men and women is 90 beats / minute, while when working is very heavy, pulse for men and women is 160 beats / minute. Then need for $\mathrm{O} 2$ when working is very heavy at $12.5 \mathrm{kcal} /$ minute (Iridiastadi, 2017)

Physiology, one of them discusses workload. Workload of each worker will be vary. It is that parameters of age, sex and body weight play an important role. These factors contribute to heart rate per minute if excessive fatigue. This assumption is in accordance with research conducted by (Argyle et al., 2021). The research also provides a statement, sense of sight has greatest impact on fatigue. The relationship of research to be carried out is related to heart rate when workforce is working. Measurement of heart rate has similarities to pulse and also has a relationship with cardiovascular. This statement is in accordance Putri, (2019).

The role of work with this type of workload will increase pulse rate. Increased pulse can have a consequent time to rest. Further research on physiology was carried out by (Chen et al., 2019). Results of study explained that $50 \%$ of workers were tired after working. Quality Function Deployment as a method of discussing product plans from user's voice (Asih et al., 2020). Quality Function Deployment role involves multiple resources. So that results of product plan will be in accordance with demand. This method can provide a product cost savings. Another advantage is that it relates design to a simulation before implementation. Research (Sandova et al., 2020) prove design based on attribute value of user needs.

Based on explanation from empirical studies, physiological approaches and Quality Function Deployment can be integrated. Integration to determine system in ongoing rest time at work. Rest system with ineffective activities in workplace raises various complaints. Review of research (Ginting et al., 2019), integration of ergonomics and Quality Function Deployment provides a design that results in reducing musculoskeletal conditions in neck, back, waist, improving quality and providing ease of use of product. Thus, renewal of research that will be carried out refers to design of rest system for tofu craftsmen in Kediri Regency. Design of this system is based on work physiology related to rest time interventions. An intervention uses parameters of pulse rate, oxygen consumption, energy use and body metabolism. Results of intervention will be informed to tofu craftsmen. Researchers spread out a questionnaire to collect attributes of needs that will be carried out during break. Process of selecting attributes uses Quality Function Deployment approach. Selection of selected attributes using highest score weight. So that selected attribute will be allocated an objective time to do it during rest hours.

Based on obstacles faced by UMKM tofu in Kediri district. The purpose of this study is to determine design of rest time system using Quality Function Deployment on basis of rest time using a physiological approach to improve performance of tofu craftsmen in Kediri district. The scope of this research is physiology of work when sifting tofu and designing a rest system with Quality Function Deployment, a workload using direct assessment and indirect assessment, needs of craftsmen using an open questionnaire and technical responses derived from questions about needs of craftsmen.

\section{Literature Review}

\section{Work Physiology}

Work physiology in this research includes pulse rate parameters, heart rate reverse percentage, cardiovascular strain percentage, relaxation, oxygen demand, energy requirements, intervention and rest time (Draghici \& Taylor, 2016). Thus, the role of work physiology as a mechanism to determine 


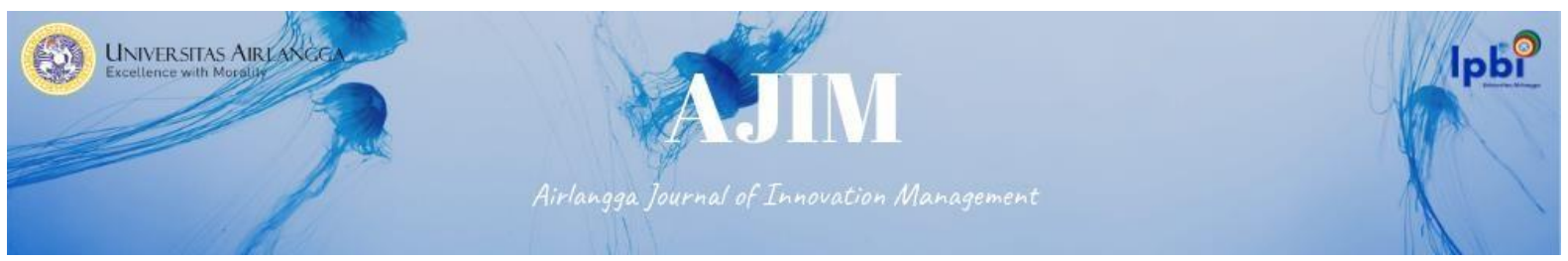

energy supply during work with achievement of determining appropriate rest time (Palilingan et al., 2020). The role of physiology in overcoming the problem of worker rest is very effective (Hermawati et al., 2014). This basis uses a multi-disciplinary approach, a conventional step to provide productivity in terms of resources and facilities to SMEs in developing countries.

\section{Quality Function Deployment}

Quality Function Deployment functions as a project knowing needs of stakeholders. Application of this method in goods and services. The basis for Quality Function Deployment is knowing needs of stakeholders associated with technical response of project developer (Hsu et al., 2017). Achievement of this method can be in form of design, indicators with greatest weight, simulation, implementation and response forms that are acceptable to stakeholders (Punchihewa, 2010).

\section{Resource Performance}

Performance is an achievement in terms of quality and quantity. These achievements have been achieved by both company and its workforce (Kurniawan \& Sidiq, 2020). Performance concerns selfefficacy and evaluation on an ongoing basis. A performance can be achieved by increasing intelligence and working methods each period (Setiawan et al., 2020).

\section{Methods / Materials}

This research was conducted in Tofu home industry which is located in Blabak, Kediri Regency. The home industry with a total of 24 tofu craftsmen. This study calculates rest time using assessment workload basis indirectly and directly at tofu filtering station (Dhiya \& Rahmah, 2019). This study used male respondents only. The primary data used a metabolism approach to assess workload (Sari et al., 2016). Secondary data refers to previous theoretical and research studies. The process of sifting out tofu with a tool load and tofu dough of $<40 \mathrm{~kg}$.

\section{A. Indirect Workload Assessment}

1. Observation of resting pulse data collection only once before work. Meanwhile, work pulse taking is done 5 times during work every 60 minutes. 1 st pulse measurement at $13.00 \mathrm{WIB}$; 2nd working pulse measurement at $14.00 \mathrm{WIB}$; 3 rd work pulse at $15.00 \mathrm{WIB}$; Measurement of 4th working pulse at 16.00 WIB; and 5th working pulse measurement at 17.00 WIB.

2. Calculating pulse at rest or at work using a formula (Suarjana, 2020):

$$
X=\frac{10 \text { pulse }}{n} \times 60
$$

Notes:

$\mathrm{X}=$ Resting Pulse (DNI) or Work Rate (DNK)

$\mathrm{n}=$ Time of calculation

3. Calculating Percentage of Reverse Heart Rate using a formula (Widodo, 2008):

$$
\% H R R=\frac{W P-R P}{P_{\max }-R P} \times 100
$$

Notes :

$\% \mathrm{HRR}=\%$ Heart Rate Reverse

$\mathrm{RP}=$ Resting Pulse

$\mathrm{WP}=$ Work Rate

PMax $=$ Male $->(220-$ age $) ;$ Female $->(200-$ age $)$ 


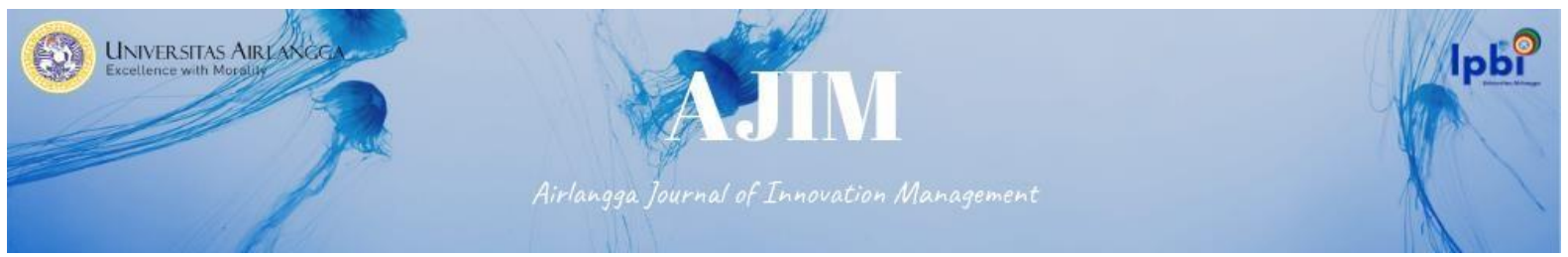

4. Calculating Percentage of Cardiovascular Strains using formula (Widodo, 2008):

$$
\% C V L=\frac{100(W P-R P)}{P_{\max }-R P}
$$

Notes :

$\% \mathrm{CVL}=\%$ Cardiovasculair Strain

$\mathrm{RP}=$ Resting Pulse

$\mathrm{WP}=$ Work Rate

PMax $=$ Male $->(220-$ age $) ;$ Female $->(200-$ age $)$

5. Relaxation to restore pulse using parameters include: P1 60 seconds first minute recovery; P2 60 second second minute recovery; P3 60 seconds third minute recovery; P3 60 seconds fourth minute recovery; and P5 60 seconds of fifth minute recovery.

\section{B. Direct Workload Assessment}

Using the oxymeter calculate the oxygen consumption (O2) units (cc) converted to (L/ $\mathrm{min})$.

C. Energy During Work and Rest

Calculate the energy at work and rest using a formula (Iridiastadi, 2017) :

$$
\begin{aligned}
& \mathrm{E}_{\mathrm{cosk}}=-55,0959+\left(H R_{k} 0,6309\right)+(\mathrm{W} 0,1988)+(\mathrm{A} 0,2017) \\
& \mathrm{E}_{\mathrm{cosi}}=-55,0959+\left(H R_{i} 0,6309\right)+(\mathrm{W} 0,1988)+(\mathrm{A} 0,2017)
\end{aligned}
$$

Notes :

$E_{\text {cosk }}=E_{\text {cosi }}=$ Energy $(\mathrm{kJ} / \mathrm{min})->(1 \mathrm{KJ} /$ minutes $=0,239 \mathrm{kkal} /$ minutes $)$

$\mathrm{HR}_{\mathrm{k}}$ dan $\mathrm{HR}_{\mathrm{i}}=$ Heart Rate Work and Heart Rate Rest (pulse/ minutes)

$\mathrm{A}=$ Age (year)

$\mathrm{W}=$ Weight $(\mathrm{kg})$

\section{Body Metabolism}

Calculate total metabolism using a formula (Widodo, 2008):

$$
\text { Met }=60 \mathrm{E}_{2}
$$

Notes :

Met= Total metabolism (Kkal/hour)

$\mathrm{E}=$ Energy $(\mathrm{kkal} / \mathrm{menit})$

$\mathrm{O}_{2}=\mathrm{O}_{2}$ Consumption $(\mathrm{L} / \mathrm{menit})$

\section{E. Energy Consumption}

Calculate energy consumption by formula (Widodo, 2008):

$$
\mathrm{K}=E_{\text {cosk }}-E_{\text {cosi }}
$$

Notes :

$\mathrm{K}=$ Energy consumption (kkal/minutes)

$\mathrm{E}_{\text {cosk }}=$ Work Energy (kkal/minutes)

$\mathrm{E}_{\text {cosi }}=$ Rest Energy (kkal/minutes)

c. Intervention 


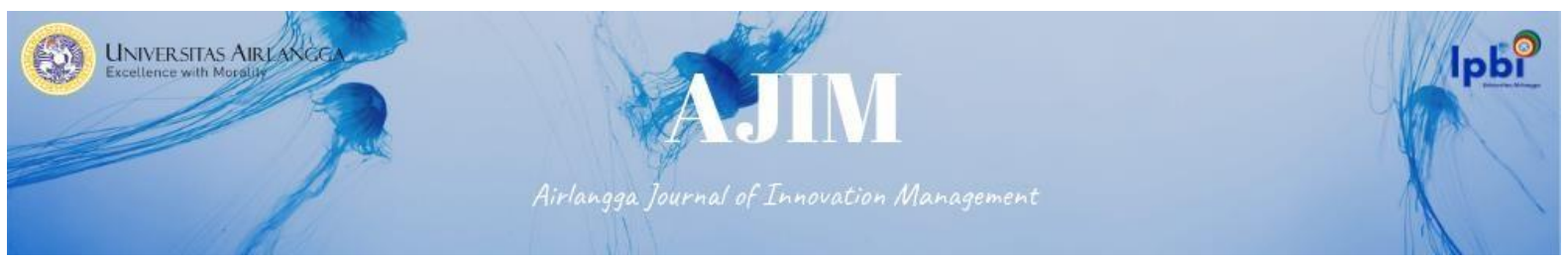

\section{F. Intervention}

Calculate need for intervention for a proper rest time using formula (Iridiastadi, 2017):

$$
R=\frac{w(b-s)}{b-0,3}
$$

Notes :

$\mathrm{R}=$ rest time (minutes)

$\mathrm{w}=$ duration of work (minutes)

$\mathrm{b}=$ energy at work (kcal / minute)

$\mathrm{s}=5.33 \mathrm{kcal} /$ minute

\section{G. Rest System Design}

The design of a rest time system is to provide useful activities for tofu craftsmen in Kediri district. System will be designed using Quality Function Deployment approach. The design stages are as follows:

1. Identify attributes of needs by calculating value of customer interests, ranking highest average value (Sulistiawan et al., 2019).

2. Test Communalities Extractions using IBM Statistics 23 Version with condition that $p$-value is $>0.05$, it is stated that attribute can be used. If $\mathrm{p}$-value $<0.05$, attribute is not used.

3. Inspection of SMEs in other areas to find out evaluation score using point identification attribute 1. Information on liker scale, namely for evaluation score, rating and target value is $1=$ not important; 1 = quite important; 3 = important; 4 = very important; and 5 = very, very important.

4. Level of importance, namely dividing target value by evaluation score.

5. Weighting value by multiplying level of importance with average value of questionnaire.

6. Linking attributes of needs of tofu craftsmen with technical response of tofu MSME owner. Percentage of weight, namely each weighted value divided by total weighted value multiplied by 100 . The symbol description includes + is better than other SMEs; ++ is much better than other SMEs; 0 is same as other SMEs; - is worse than other SMEs; and - is very much more laborer than other SMEs (Sandova et al., 2020).

7. Selection and design of selected criteria based on weight of highest score as many as 5 criteria.

\section{Results and Discussion}

The calculation results of resting pulse (DNI) and working pulse rate (DNK) is taken using average formula (1), percentage of Heart Rate Reverse (\% HRR) is taken using average formula (2), percentage of Cardiovasculair strains (\% CVL) ) is taken average using formula (3), results of relaxation pulse rate are taken average and average oxygen consumption is as follows: 


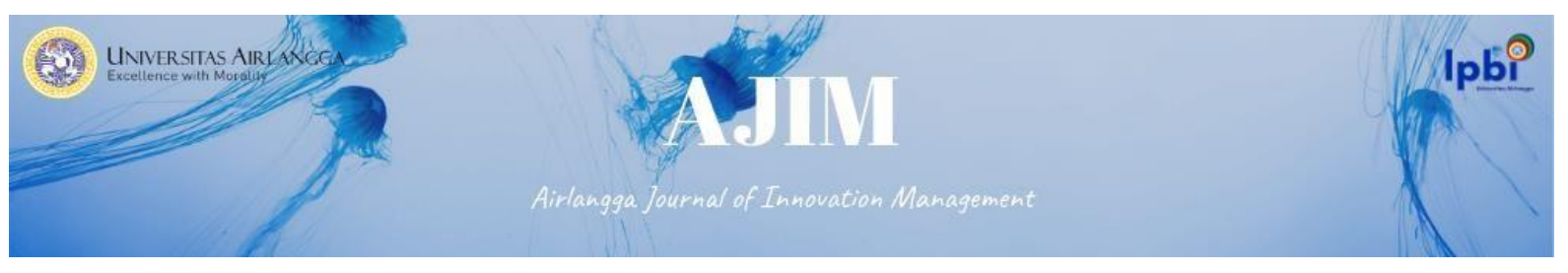

Table 1. Recapitulation of primary research data

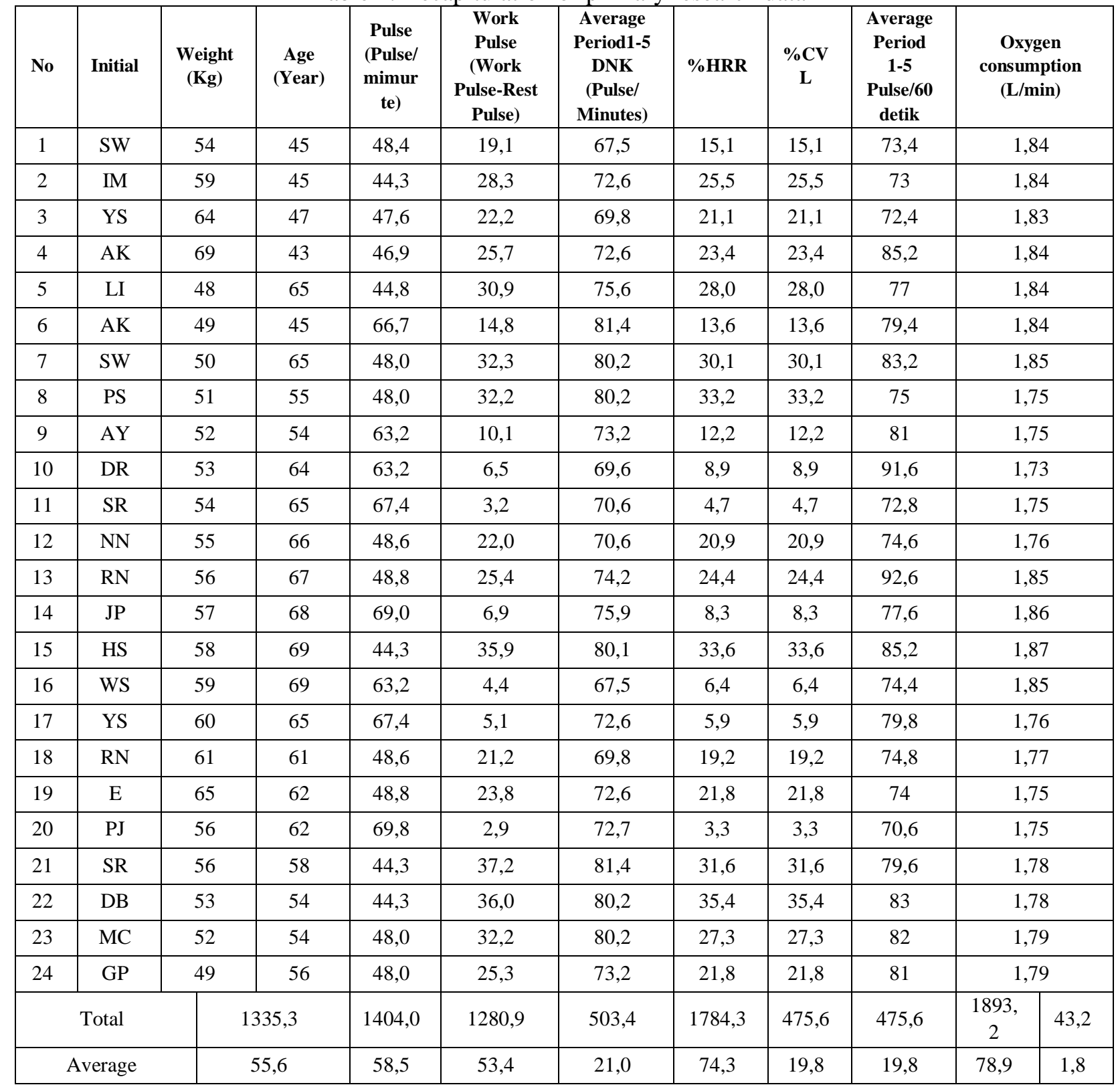

(Source: observation and primary research data processing, 2021)

Table (1) shows respondent's initials, age and weight, DNI (Resting Pulse), Work Rate (DNK-DNI), Average Period 1-5 DNK (Beats / Minute),\% HRR,\% CVL, Average -Mean period 1-5 beats / 60 seconds and oxygen consumption ( $\mathrm{L} / \mathrm{min}$ ). Respondents of this study used men with an average body weight of $55.6 \mathrm{~kg}$. For ages with an average of 58.5 years. The value of Heart Rate Reverse (\% HRR) and Cardiovasculair Strain (\% CVL) with an average of $19.8 \%$ each. 

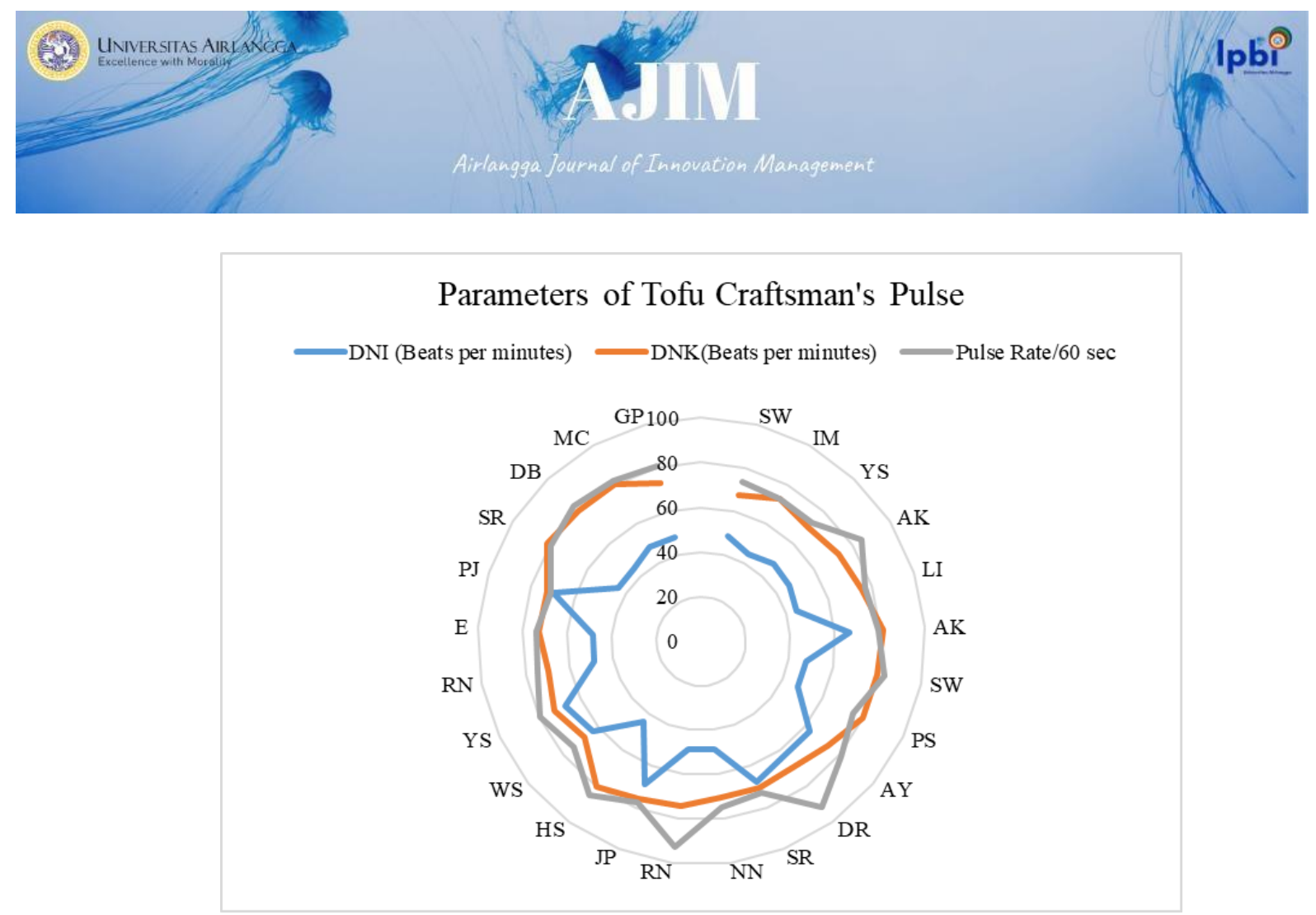

Picture 1. Pulse Parameters of Tofu Craftsmen

In figure (1) review pulse using several parameters. This parameter uses resting pulse (DNI) with an average of 53.4 beats / minute, working pulse (DNK) with an average of 74.3 beats / minute and average pulse rate for each period of 60 seconds on average. - an average of 78.9 beats, minutes. According to (May, 2010), pulse has a role in work activities, rest and post-work recovery.

From table (1), next step is to calculate energy at work and energy at rest using formula (4) and (5).

Table 2.

Energy Needs at Work and Rest

\begin{tabular}{|c|c|}
\hline $\mathrm{E}_{\text {cosk }}$ & $14,67 \mathrm{kkal} /$ minutes \\
\hline $\mathrm{E}_{\mathrm{cosi}}$ & $1,44 \mathrm{kkal} / \mathrm{minutes}$ \\
\hline
\end{tabular}

(Source: primary research data processing, 2021)

In table (2), this is result of energy demand value at work of $14.67 \mathrm{kka} /$ minute. Meanwhile, at rest, it is $1.44 \mathrm{kcal} . m i n u t e s$. Metabolic needs of workers at work and at rest use calculation formula (6). The recapitulation is as follows:

Table 3.

Worker Metabolism at Work and Rest

\begin{tabular}{|c|c|}
\hline Met $_{\mathrm{k}}$ & $1585,68 \mathrm{kkal} / \mathrm{jam}$ \\
\hline Met $_{\mathrm{i}}$ & $155,22 \mathrm{kkal} / \mathrm{jam}$ \\
\hline
\end{tabular}

(Source: primary research data processing, 2021)

In table (3), results of metabolism at work are $1585.68 \mathrm{kcal} /$ hour and metabolime at rest is $155.22 \mathrm{kcal} /$ hour.

Tofu craftsmen do job of filtering tofu dishes using energy consumption. Energy consumption for energy uses the formula (7) with following results: 


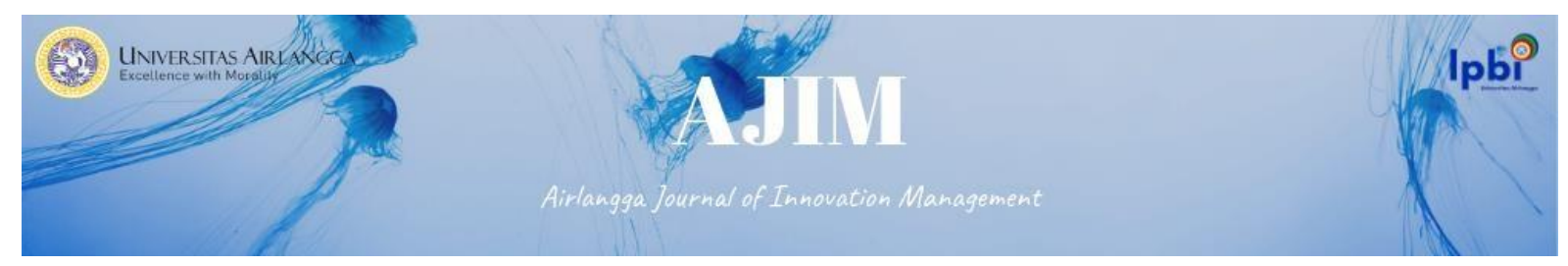

Table 4.

Worker Energy Consumption

\begin{tabular}{|c|c|}
\hline $\mathrm{K}$ & $13,23 \mathrm{kkal} / \mathrm{jam}$ \\
\hline
\end{tabular}

(Source: primary research data processing, 2021)

Table (4) shows energy consumption of workers. The energy consumption value of $13.23 \mathrm{kcal} /$ hour is obtained from Ecosk-Ecosi value.

Measurement of intervention time to determine allowance of tofu craftsmen at rest. The value of time for rest using the formula (8) with following results:

Table 5. Effective Time of Worker Rest

\begin{tabular}{|c|c|}
\hline $\mathrm{R}$ & 233,9 minutes \\
\hline
\end{tabular}

(Source: primary research data processing, 2021)

Table (5) shows effective time for worker rest for 233.9 minutes after working.

After knowing rest time based on a physiological approach. Researcher made a questionnaire on a Likert scale of $1-5$ to be filled out by tofu craftsmen.

Table 6.

Assessment of Needs of Tofu Craftsmen

\begin{tabular}{|c|l|c|c|c|c|}
\hline No. & \multicolumn{1}{|c|}{ Needs Attributes } & $\begin{array}{c}\text { Customer } \\
\text { Interest }\end{array}$ & Ranking & $\begin{array}{c}\text { Communalities } \\
\text { Extraction } \\
(\mathrm{CE})\end{array}$ & $\begin{array}{c}\text { Notes (CE > } \\
0,5)\end{array}$ \\
\hline 1 & Time adequacy & 1,13 & 12 & 0,646 & Used \\
\hline 2 & Work motivation & 3,67 & 9 & 0,862 & Used \\
\hline 3 & Meals consumption & 3,42 & 11 & 0,863 & Used \\
\hline 4 & Snack consumption & 3,58 & 10 & 0,926 & Used \\
\hline 5 & Fruits consumption & 3,70 & 4 & 0,914 & Used \\
\hline 6 & Water consumption & 4,88 & 2 & 0,727 & Used \\
\hline 7 & Enough rest (sleep) & 4,67 & 3 & 0,694 & Used \\
\hline 8 & Pray & 4,92 & 1 & 0,858 & Used \\
\hline 9 & Relaxation after work & 3,71 & 8 & 0,768 & Used \\
\hline 10 & Warming up before work & 3,92 & 6 & 0,850 & Used \\
\hline 11 & Workload evaluation & 4,04 & 5 & 0,665 & Used \\
\hline 12 & Focus Group Discussion & 3,83 & 7 & 0,755 & Used \\
\hline
\end{tabular}

(Source: primary research data processing, 2021)

Table (6) is a statement that has been filled in by tofu craftsman. Statement totaling 12 items. Filling in questionnaire to get value of customer importance is 4.92, namely Worship with rank 1 while smallest is 1.13 , which is a relatively long time with a ranking of 12 . All statement items can be used with evidence of value of Communalities Extraction> 0.5.

The consideration of rest system refers to all statement items and uses one of SMEs know in another area as a comparison competitor. 


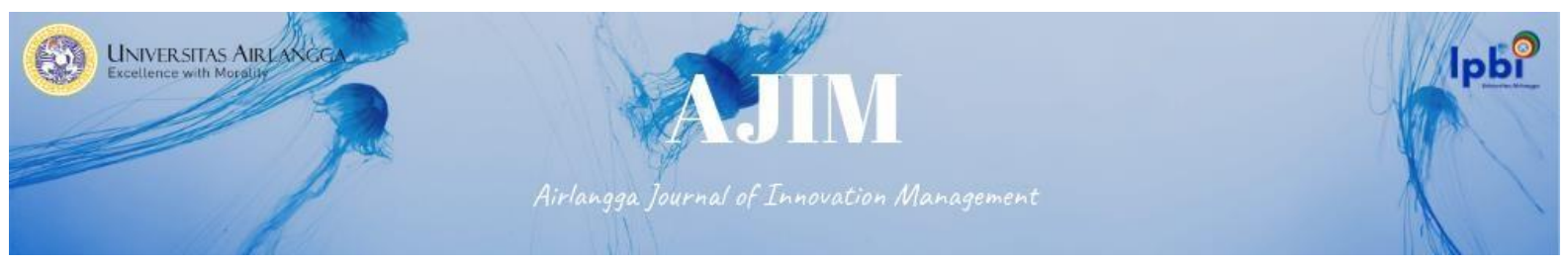

Table 7.

Objective Assessment of Rest Systems

\begin{tabular}{|l|c|c|c|c|c|c|}
\hline \multicolumn{1}{|c|}{ Needs attributes } & $\begin{array}{c}\text { Evaluation } \\
\text { score }\end{array}$ & $\begin{array}{c}\text { Target } \\
\text { value }\end{array}$ & $\begin{array}{c}\text { Interest } \\
\text { Level }\end{array}$ & $\begin{array}{c}\text { Customer } \\
\text { needs }\end{array}$ & Weight & $\%$ Weight \\
\hline Time adequacy & 2 & 1 & 0,50 & 1,13 & 0,57 & 2 \\
\hline Work motivation & 2 & 3 & 1,50 & 3,67 & 5,50 & 17 \\
\hline Meals consumption & 2 & 2 & 1,00 & 3,42 & 3,42 & 11 \\
\hline Snack consumption & 2 & 3 & 1,50 & 3,58 & 5,38 & 17 \\
\hline Fruits consumption & 2 & 4 & 2,00 & 3,70 & 7,40 & 23 \\
\hline Water consumption & 2 & 4 & 2,00 & 4,88 & 9,75 & 30 \\
\hline Enough rest (sleep) & 2 & 5 & 2,50 & 4,67 & 11,67 & 36 \\
\hline Pray & 2 & 5 & 2,50 & 4,92 & 12,29 & 38 \\
\hline Relaxation after work & 2 & 3 & 1,50 & 3,71 & 5,56 & 17 \\
\hline Warming up before work & 2 & 5 & 2,50 & 3,92 & 9,79 & 31 \\
\hline Workload evaluation & 2 & 5 & 2,50 & 4,04 & 10,10 & 32 \\
\hline Focus Group Discussion & 2 & 3 & 1,50 & 3,83 & 5,75 & 18 \\
\hline \multicolumn{7}{|l|}{ Total } \\
\hline
\end{tabular}

(Source: primary data processing, 2021)

In table (7) attribute items are equated between tofu SMEs of other regions with SMEs studied. The value of evaluation score of tofu SMEs in other regions is 2 with quite important information. Meanwhile, expected value target of Tofu SMEs in Kediri Regency is a value of 1 with insignificant information, a value of 2 with information that is quite important, a value of 3 with important information, a value of 4 with very important information and a value of 5 with very, very important information. The weight value comes from level of importance multiplied by average value of questionnaire. While the \% weight value comes from each attribute divided by total weight multiplied by 100 .

Table 8.

Weight Assessment of Selected Attributes

\begin{tabular}{|c|c|c|c|c|c|c|}
\hline \multirow{2}{*}{ No } & \multirow{2}{*}{ Selection Criteria } & \multirow[t]{2}{*}{ Technical Response } & \multirow{2}{*}{$\begin{array}{l}\text { Value } \\
\text { symbol }\end{array}$} & \multirow{2}{*}{$\begin{array}{c}\% \\
\text { Weight }\end{array}$} & \multicolumn{2}{|c|}{ Assessment } \\
\hline & & & & & Rating & Score \\
\hline 1 & Time adequacy & Agreement to reduce rest hours & -- & 2 & 1 & 1,77 \\
\hline 2 & Work motivation & Do in once a week & + & 17 & 4 & 68,74 \\
\hline 3 & Meals consumption & Allocating time in the weekend & -- & 11 & 1 & 10,67 \\
\hline 4 & Snack consumption & Allocating time in the weekend & 0 & 17 & 3 & 50,38 \\
\hline 5 & Fruits consumption & Allocating time in the weekend & + & 23 & 4 & 92,48 \\
\hline 6 & Water consumption & Allocating time in the weekend & + & 30 & 4 & 121,85 \\
\hline 7 & Enough rest (sleep) & Suggestion from Tofu owner & ++ & 36 & 5 & 182,25 \\
\hline 8 & Pray & Suggestion from Tofu owner & ++ & 38 & 5 & 192,02 \\
\hline 9 & Relaxation after work & Suggestion from Tofu owner & ++ & 17 & 5 & 86,90 \\
\hline 10 & Warming-up before work & Suggestion from Tofu owner & ++ & 31 & 5 & 152,96 \\
\hline 11 & Workload evaluation & Urgent to do in once a week & ++ & 32 & 5 & 157,84 \\
\hline 12 & Focus Group Discussion & Urgent to do in once a week & + & 18 & 4 & 71,86 \\
\hline \multicolumn{3}{|c|}{ (a) Amount +} & 4 & \multirow{4}{*}{\multicolumn{2}{|c|}{ Total }} & \multirow{4}{*}{224,04} \\
\hline \multirow{2}{*}{\multicolumn{3}{|c|}{ (c) Amount - }} & 1 & & & \\
\hline & & & 1 & & & \\
\hline \multicolumn{3}{|c|}{ Score $(c)+0-(a)$} & 3 & & & \\
\hline
\end{tabular}




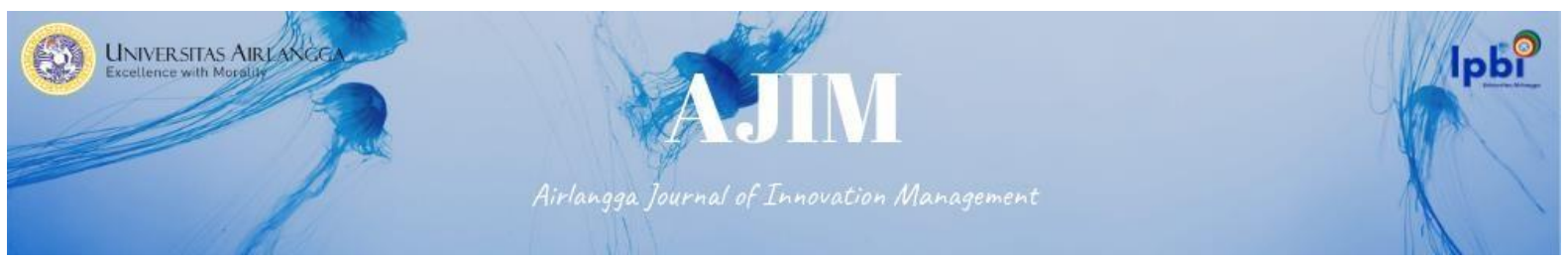

(Source: primary data processing, 2021)

In table (8), it shows criteria selected from attribute statements with technical response. The very better relationship with ++ sign is worship, adequate sleep, pre-work warm-up, post-work stretching, workload evaluation. The highest weight will be used as a reference for developing a resting system in tofu craftsmen. The weights are selected in amount of 5 selection criteria.

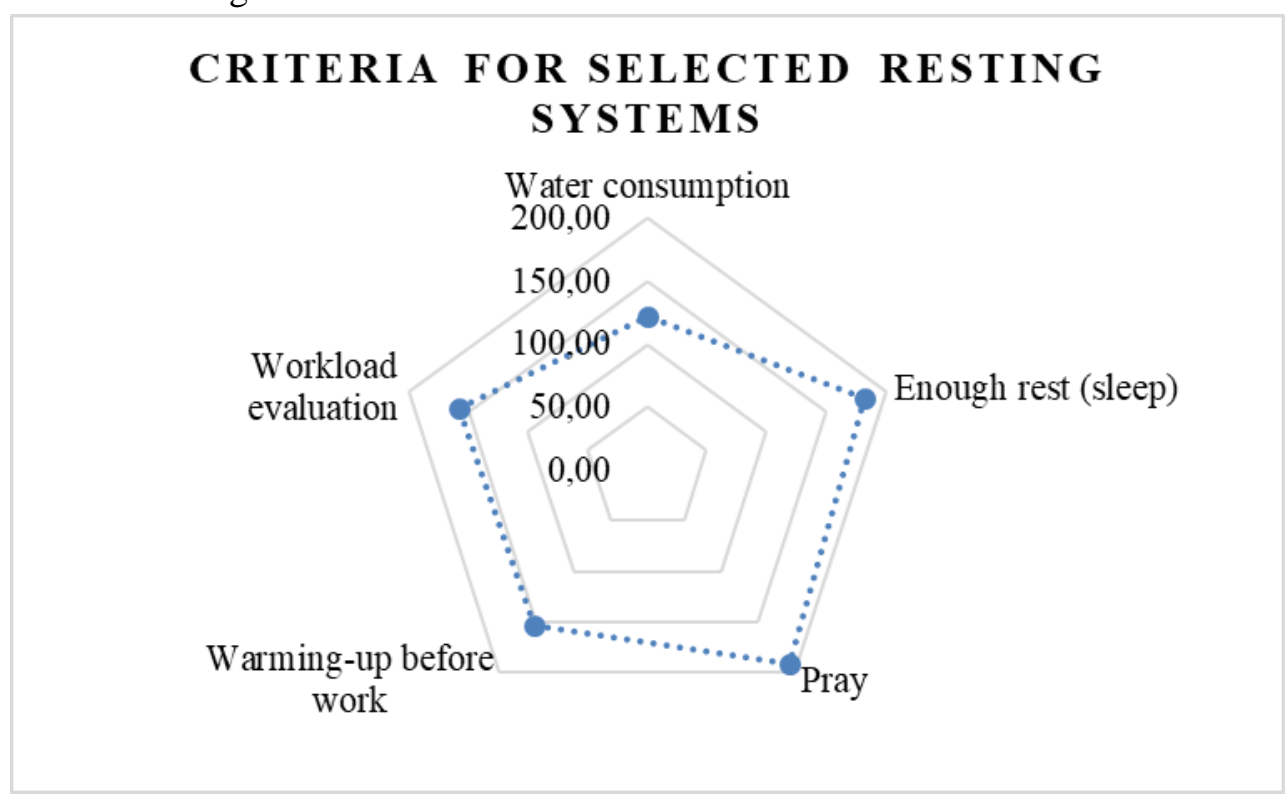

Figure 2. Criteria for Selected Resting Systems

(Source: primary data processing, 2021)

Figure (2) shows selected criteria, including worship with a weighted score of 192.02; Get enough sleep with a weight score of 182.25; Evaluation of workload with a weight score of 157.84; Pre-work heating with a weight score of 152.96; and drinking water with a weight score of 121.85.

Based on value of rest time, tofu craftsmen used a physiological approach with a time of 233.9 minutes. Meanwhile, attributes expected by craftsmen to fill rest time using Quality Function Deployment approach include worship, adequate sleep, workload evaluation, pre-work heating and drinking water. Researchers arranged these attributes based on time of rest. So objectively designing a rest system for tofu craftsmen to improve performance as follows:

a. Worship is carried out for Muslims and non-Muslims within 20 minutes.

b. Adequate sleep as a step to refresh body. Effective sleep is given in 60 minutes.

c. Evaluation of workload for craftsmen is an activity of mutual communication between colleagues within 120 minutes.

d. A pre-work warm-up is performed to relieve symptoms of musculoskeletal disorders in 20 minutes.

e. Drinking water is an activity to replenish body fluids with a flexible time during breaks, namely time assumption is 13.9 minutes. This activity can be done when doing points $\mathrm{a}, \mathrm{b}, \mathrm{c}$ and.

f. Thus, performance of tofu craftsmen is expected to increase after it is known that rest system design is based on rest time with a physiological approach and development of attributes of needs using Quality Function Deployment approach. 


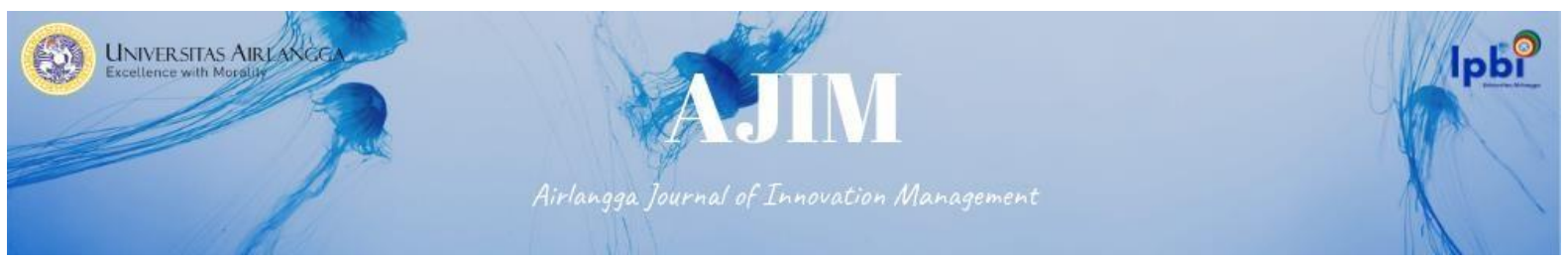

\section{Conclusion}

Based on objectives of this study, conclusion in improving performance of tofu craftsmen in Kediri Regency refers to results of physiological approach and system design using Quality Function Deployment approach. 24 respondents had an average pulse period of $1-5$ of 78.9 beats / minute post work. Meanwhile, $\mathrm{O} 2$ consumption uses an oxymeter with an average of 1.8 liters / minute. Thus, value of intervention for resting time is 233.9 minutes. In duration of break, design of activities to improve performance of tofu craftsmen includes worship for 20 minutes, sleep for 60 minutes, evaluation of workloads with 120 minutes, pre-work warm-up with 20 minutes and drinking water to fill body fluids with time. 13.9 minutes. This research is not said to be perfect. Therefore, future development is very important. For next researcher is to evaluate rest time so that it does not exceed duration of 60 minutes, but can provide a significant performance increase, providing a layout design for tofu screening process from an anthropometric point of view.

\section{Acknowledgements}

Thank you to Tofu UMKM in Kediri Regency for participating in this research. We would like to thank to Kadiri University, especially S-1 Industrial Engineering Study Program, Faculty of Engineering, for providing a reading room and library to gather information to support this research.

\section{References}

Argyle, E. M., Marinescu, A., Wilson, M. L., Lawson, G., \& Sharples, S. (2021). Physiological indicators of task demand, fatigue, and cognition in future digital manufacturing environments. International Journal of Human Computer Studies, 145(July 2020), 102522. https://doi.org/10.1016/j.ijhcs.2020.102522

Asih, E. W., Mawadati, A., \& Lestari, N. (2020). Ergonomic Design for Tempe Production Tool Based on User Voice. IOP Conference Series: Materials Science and Engineering, 807(1). https://doi.org/10.1088/1757-899X/807/1/012037

Caldwell, J. A., Caldwell, J. L., Thompson, L. A., \& Lieberman, H. R. (2019). Fatigue and its management in the workplace. Neuroscience and Biobehavioral Reviews, 96(October 2018), 272 289. https://doi.org/10.1016/j.neubiorev.2018.10.024

Chen, M. L., Lu, S. Y., \& Mao, I. F. (2019). Subjective symptoms and physiological measures of fatigue in air traffic controllers. International Journal of Industrial Ergonomics, 70(110), 1-8. https://doi.org/10.1016/j.ergon.2018.12.004

Dhiya, P. Y., \& Rahmah, D. M. (2019). Mental Workload and Ergonomic Analysis on Production Departement At PT. XYZ. Journal of Industrial and Information Technology in Agriculture, 2(1), 1-11. https://doi.org/10.24198/jiita.v2i1.17720

Draghici, A. E., \& Taylor, J. A. (2016). The physiological basis and measurement of heart rate variability in humans. Journal of Physiological Anthropology, 35(1), 1-8. https://doi.org/10.1186/s40101-016-0113-7

Ginting, R., Tarigan, U., \& Panjaitan, N. (2019). The Application of Quality Function Deployment and Ergonomics: A Case Study for A New Product Design of A Texon Cutting Tool. IOP Conference Series: Materials Science and Engineering, 495(1), 0-9. https://doi.org/10.1088/1757899X/495/1/012009

Hermawati, S., Lawson, G., \& Sutarto, A. P. (2014). Mapping ergonomics application to improve SMEs working condition in industrially developing countries: a critical review. Ergonomics, 57(12), 1771-1794. https://doi.org/10.1080/00140139.2014.953213 


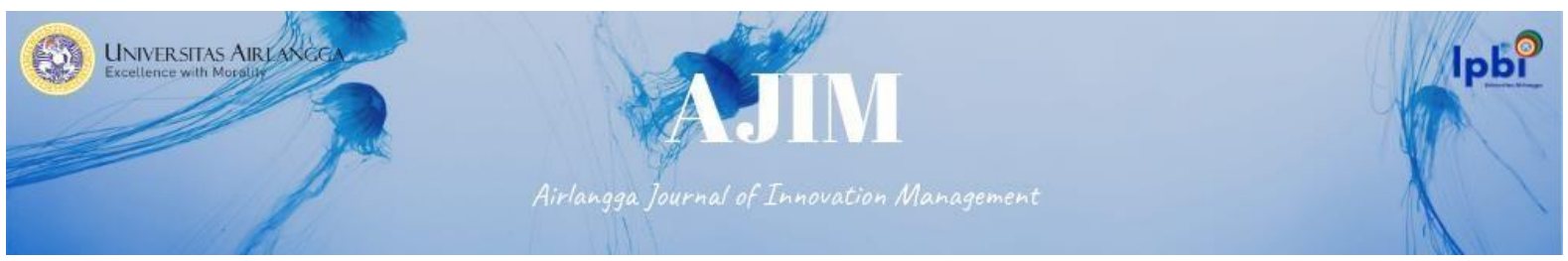

Hsu, C. H., Chang, A. Y., \& Luo, W. (2017). Identifying key performance factors for sustainability development of SMEs - integrating QFD and fuzzy MADM methods. Journal of Cleaner Production, 161, 629-645. https://doi.org/10.1016/j.jclepro.2017.05.063

Iridiastadi, H. dan Y. (2017). Ergonomi Suatu Pengantar (4th ed.). PT. Remaja Rosdakarya.

Kurniawan, M., \& Sidiq, A. N. (2020). INOVASI PERANCANGAN INSENTIF UNTUK MENINGKATKAN KINERJA PADA PERUSAHAAN CLEANING SERVICE ONLINE. Airlangga Journal of Innovation Management, 21(1), 1-9. http://journal.umsurabaya.ac.id/index.php/JKM/article/view/2203

Palilingan, R. A., Tirtayasa, K., \& Surata, I. W. (2020). Ergonomic-Based Redesign of Broomsticks Reduces the Physiological Burdens of Street Sweepers in Denpasar City, Indonesia. Jurnal Ergonomi Indonesia (The Indonesian Journal of Ergonomic), 6(2), 113. https://doi.org/10.24843/jei.2020.v06.i02.p05

Punchihewa, H. K. G. (2010). The potential of Quality Function Deployment ( QFD ) in reducing workrelated musculoskeletal disorders. Loughborough University.

Putri, E. V. (2019). The Correlation between Physical Workload and the Increase in Workers' Pulse Rate. The Indonesian Journal of Occupational Safety and Health, 8(2), 206. https://doi.org/10.20473/ijosh.v8i2.2019.206-214

Sandova, D. R., Safi'i, I., \& Tripariyanto, A. Y. (2020). Pengembangan Produk Kursi Tunggu Multifungsi Dengan Menggunakan Metode Quality Function Deployment (QFD). JURMATIS : Jurnal Ilmiah Mahasiswa Teknik Industri, 2(1), 32. https://doi.org/10.30737/jurmatis.v2i1.861

Sari, A. D., Suryoputro, M. R., Pramaningtyas, M. D., Putra, P. S., \& Maulidyawati, S. B. (2016). Work Physiology Evaluation of Laundry Workers. IOP Conference Series: Materials Science and Engineering, 105(1). https://doi.org/10.1088/1757-899X/105/1/012034

Setiawan, N., Maisyarah, R., \& Harahap, R. (2020). ANALYSIS OF EMOTIONAL INTELLIGENCE AND WORK DISCIPLINE ON EMPLOYEE PERFORMANCE WITH ORGANIZATIONAL COMMITMENT AS AN INTERVENING VARIABLE. Airlangga Journal of Innovation Management, 1(2), 184-206.

Suarjana, I. W. G. (2020). Analisis Beban Kerja Mahasiswa Praktikum Parasitologi Di Program Studi Ilmu Kesehatan Masyarakat Universitas Negeri Manado Workload Analysis on Parasitology Practicum Students at Public Health Study Program at Manado State University Program Studi Ilmu Ke. Jurnal Ergonomi Indonesia (The, 06(01), 45-51.

Sulistiawan, I., Santoso, H. B., \& Komari, A. (2019). Perancangan Produk Kep Potong Rambut Dengan Mempertimbangkan Voice Of Customer Menggunakan Metode Quality Function Deployment. JATI UNIK: Jurnal Ilmiah Teknik Dan Manajemen Industri, 2(1), 46. https://doi.org/10.30737/jatiunik.v2i1.386

Widodo, S. (2008). Penentuan Lama Waktu Istirahat Berdasarkan Beban Kerja Dengan Menggunakan Pendekatan Fisiologis. In Jurnal UMS (Issue 29). 